\title{
The Influence of Modified Dakon on the Understanding of the Concept of Numbers and Motor Abilities
}

\author{
Nia Aminatus Sholihah, Mustaji, Miftakhul Jannah \\ Universitas Negeri Surabaya \\ Surabaya, Indonesia \\ niaaminatussholihah@gmail.com
}

\begin{abstract}
This quantitative research aims to examine the influence of Modified dakon on the ability to understand the concept of numbers and motor abilities of children group $A$. Research children aged 4-5 years at RA STAI Laboratorium background by the lack of ability to count numbers 1-10. The population of this research is children of group $A$ at RA Laboratorium STAI Rewwin Waru Sidoarjo which amounts to 25 children. Data collection techniques in this study using observation and documentation. Based on the research that has been done then the data obtained from the average value before being treated (pre-test) is 3.33 while the average value after being treated (post-test) is 7.29. The result of data analysis shows that $\mathbf{T}$ arithmetic $=0$ is smaller than $\mathbf{T}$ table with significant level $5 \%(0.05)=0.5$ so $\mathrm{Ha}$ is accepted and Ho is rejected. Thus, it can be stated that the use of Modified dakon has an effect on the ability to understand the concept of child number and motor ability of A group on children in RA Laboratorium STAI Rewwin Waru Sidoarjo.
\end{abstract}

\section{Keywords-Dakon;Concept Number;Motor Abilities}

\section{INTRODUCTION}

The child is a generation of people who are in the golden age. In this golden age, children begin to be sensitive to receive various kinds of stimuli. Sensitivity to each child is different, along with the rate of growth and development individually. Sensitive or commonly called the golden period is the period where the child's brain develops most quickly throughout the history of his life. In infancy in the womb until birth and until the age of four years is the most decisive period. This period is a golden period or more lasting when the child in the womb until the early age, which is 0-6 years.

Early childhood according to [1] is the figure of an individual who is undergoing a process of development with the center and fundamental for the next life. Early childhood is in the age range 0-6 years. At this time, children experience rapid growth and development in various aspects. The child's ability to grow and develop cannot just come. There are several stages to go through, in which stimulus from the environment to support its development optimally is necessary. Early childhood education is necessary to make sure the stimulation or support is provided.

One of the basic skills children need to develop is cognitive ability. Cognitive ability is a process of thinking, namely the ability of individuals to relate an event [2]. Cognitive development is the development of the mind. The mind is part of the thinking process of the brain. The mind can be used to solve a problem quickly and precisely. The mind can also be used to recognize, know, and understand. [1] argues that cognitive development is divided into 4 sensory of motor phases, children begin to interact with the world around through the five senses. The next stage is the pre-operational phase, where the child's initial period builds his ability in arranging his thoughts. In the concrete operation phase, the child already has the ability to think logically with the condition of the object that the source of thinking is present in concrete. The last phase of the formal operation phase is that children can think abstractly like the ability to propose ideas and predict the events that will occur.

[3] Regulation of the Minister of Education and Culture of the Republic of Indonesia on the national standard of early childhood education on the aspects of cognitive development reveals that children aged 4-5 years should have been able to spell out numbers one to ten and understand the concept in symbol number. [2] suggests that at the age of 4-5 years is a period of learning mathematics. At this stage, the child begins to learn simple math such as mentioning numbers and calculating the order of numbers. Mathematics learning in early childhood can be taught through the media of play, because the age of 4-5 years is the age of the game for the child. Playing also gives opportunities for children to 
create, shape, discover, and build using existing media, such as playing clay or plasticine and playing blocks.

According to Rani Yulianty, playing congklak can train smart children to count. In addition, children who play congklak must be good at making strategies to win the game. The game called Dakon in Javanese is usually played by two children.

Method is one of the important factors in improving the counting ability of Kindergarten children. Often the success or failure of counting programs in children is associated with the method used by teachers in learning, because the method has an important role in achieving the goal of improving numeracy skills in kindergarten. With a good and appropriate method, the purpose of improving the ability to counting is expected to be maximized.

The method of playing is a method of teaching where the teacher provides opportunities for the child to perform activities to play a particular game as contained in everyday life. Playing has several meanings, another element of play is repetition with repetition of the child gets the chance to consolidate Its ability, simple game can be a vehicle to become so complex game play, through playing child can safely state its need, in all games he can express his hatred, fear and emotional distress.

It is said that the ability to count or mathematical intelligence is the ability to use reasoning, logic, and numbers. Logical/mathematical learner thinks conceptually in the form of logical and numerical patterns, searching for connections between pieces of information. They ask a lot and love to experiment. One of the new ways of teaching arithmetic in children is through learning cablak game in children related to everyday life.

Ways to improve children's numeracy skills should not always use the old ways of using the formula, because this old way can lead to failure in children. In line with this, a child has a good talent in the field of arithmetic and mathematics. Unfortunately, he was not taught mathematical theory the right way. Instead, he was taught mathematical theories in the wrong way. The result is undoubtedly the child does not have to always struggle with serious formulas, but can be tucked into everyday activities. Like through the game, so indirectly we have taught the children about the concept of addition and subtraction.

In this study, Modified dakon is one of the learning media. It is said that the teaching medium consists of medium and device. In the sense of this medium, teaching media is more about materials and tools, but also the people who provide them and who operate them, their use, organizing and processing, and how they interact with children, which prioritizes Ability, is not the same as learning mathematics in Primary, Secondary and High
School, because there are some conditions that must be created in teaching and learning process to achieve the planting ability and the development of numeracy skills. For that required more varied methods such as playing congklak. The game of this method and is intended for the purpose of improving numeracy skills for Kid's kindergarten children. Improvement of numeracy skills in kindergarten is situational, then the method that is suitable to use is the method of play. The lecture, storytelling, drill, and assignment methods do not touch the aspect of Abilities, whereas numerical materials in Kindergarten are required to touch into all aspects of education i.e. cognitive, affective and psychomotor.

Fine motor skills are just beginning to develop which begins with simple activities such as holding a pencil, holding a spoon, and stirring. Fine motor skills develop longer than gross-motor, because fine motor skills require concentration, control, caution, and auto to-muscle coordination. As the child's age increases, his fine motor skills will continue to grow.

However, the observations in several RA Waru region still found a lot of subtle motor skills of children who have not developed, for example when macrame children always asked for help, when writing children less precisely helped pencil, when sewing children did not fit the pattern, and when grazing objects often fell. The researchers' understanding of the importance of fine motor development encourages the researcher to find ways to optimize the fine motor skills of children through a media game that can optimize the smooth motor development of children.

Teachers should be able to create games that invite the curiosity of children, interests to something new immediately responded by the teacher and feedback is able to improve the ability to count children. Action taken by the teacher is to use game Modified dakon of egg container to improve cognitive so that children can understand the concept of numbers and connect the concept of the number of objects. From the above phenomenon, the researcher is interested to pour into the thesis entitled "The Influence of Modified dakon on the Understanding of the Concept of Numbers and Motor Abilities".

\section{METHOD}

The research approach used is quantitative research with experimental research model, where the researcher gives treatment in the form of learning by using Modified dakon media and doing observation of student learning activity in class and doing measurement before and after giving treatment.

The research was conducted using experimental design or experimental model design, where this design 
has a control group but cannot fully function to control the external variables affecting experimental execution. This study uses Nonequivalent Control Group Design, where the experimental group and the control group are not selected randomly [4]. The main difference between quasi-experiment and randomized-experiment lies in the way the division of research groups[5]. The design of this study can be described as follows:

Table 3.1 RESEARCH DESIGN SCHEME INFLUENCE MODIFIED DAKON TO ABILITY TO KNOW CONCEPT OF NUMBERS AND SUBTLE MOTOR CAPABILITIES OF KINDERGARTEN CHILDREN GROUP A

\begin{tabular}{|l|c|c|c|}
\hline \multicolumn{1}{|c|}{ Group } & $\begin{array}{c}\text { Before } \\
\text { Activity }\end{array}$ & Treatment & $\begin{array}{c}\text { After } \\
\text { Activities }\end{array}$ \\
\hline Experiment & $\mathrm{O}_{1}$ & $\mathrm{X}$ & $\mathrm{O}_{2}$ \\
\hline Control & $\mathrm{O}_{3}$ & - & $\mathrm{O}_{4}$ \\
\hline
\end{tabular}

Information :

$\mathrm{O} 1$ = Initial observation result (pretest) experimental group

$\mathrm{O} 2$ = Result of final observation (postest) experiment group

O3 = Final observation result (pretest) of control group

$\mathrm{O} 4=$ The result of final observation (postest) of the control group

$\mathrm{X}=$ Experiment Group treated with media modification Dakon

- = The control group is not treated

Explanation of the above design scheme is before the treatment begins, both groups, i.e. experimental and control group were given pretest to measure the initial condition (O1 and $\mathrm{O} 3$ ), then the experimental group is given treatment $(\mathrm{X})$ and in the control group is not given treatment. After treatment was completed, both groups were equally given pos-test ( $\mathrm{O} 2$ and $\mathrm{O} 4)$. In the above scheme, it is known that the effectiveness of treatment is addressed by the difference between $(\mathrm{O} 1$ and $\mathrm{O} 2)$ and in the experimental group with $(\mathrm{O} 3$ and $\mathrm{O} 4)$ in the control group.

In this experimental research, researchers divide the two groups namely, the experimental group and the control group. Both groups have similar or near-same characteristics and characteristics. In the experimental group was given treatment by giving Modified dakon media, while in the control group in the learning did not use Modified dakon media. Furthermore, the research process was observed to determine the differences that occurred in the experimental group.

\section{B. Operational Variables and Definitions of Research}

Variable Research is anything in the form of what is determined by the researcher to be studied so that obtained information about it, then can be drawn conclusion.

\section{Research Variables}

Quantitative research is used to test the hypothesis of the relationship between research variables[6]. The variables studied in the study consist of:

\section{a. Dependent Variable}

Dependent variables are variable $\mathrm{Y}$ that is influenced or which becomes due to the existence of independent variables. It is called dependent variable because this is influenced by independent variable. So it can be summarized that the dependent variable is the variable measured in an experiment to see if there are changes after the free variable is given[5]The dependent variable in the research consists of 2, namely:

Y1: Variable Ability to understand the concept of child number

Y2: Variable Motor Fine Motor Ability

\section{b. Independent Variables}

Independent variable is also called variable X[5] that cause of change or incidence dependent variable (bound). This variable is free in influencing other variables. This free variable is Modified dakon (X).

The design of independent variable relationship is Modified dakon (X) with dependent variable that is ability to understand the concept of number ( $\mathrm{Y} 1$ and fine motor ability (Y2), described as follows:

\section{Operational Definition of Variables}

\section{a. Modified dakon}

Media Modified dakon is a game designed to attract attention, clarify the dish through numbers or numbers1-10 so that the learning process can run more fun and children will be easier in understanding the concept of numbers 1-10 and fine motor ability to train the hand muscles.

\section{b. Know the Concept of Numbers}

Knowing the concept of numbers is an ability to understand the symbols of numbers 1-10 in the form of numbers measured based on the symbol indicator of numbers consisting of knowing the concept of many and little, counting objects from one to ten, to know the concept of numbers, to understand the number symbols and call numbers 1 - 10 .

\section{c. Smooth Motorist Capability}

Smooth motor skills are capabilities related to physical Ability involving small muscles and eye-hand coordination. Fine motor nerves can be trained and developed through routine continuous activities and 
stimuli. Learning outcomes to be achieved in the use of Modified dakon media is a child is able to coordinate the eyes and hands to do the movement of taking, pointing, putting, able to put objects in accordance with the concept of numbers.

\section{Research Subject}

1. Population

According to[5] the population is an individual with a whole that has certain characteristics of the same, such as age factor, geographical location and so forth. While [7] suggests the population is a generalization region consisting of objects/subjects that have certain qualities and characteristics set by researchers to be studied and then drawn conclusions in line with it[8] explains that the population is the whole subject research that has characteristics to be studied. The population in this study was all children of group A RA STAI Laboratory Jalan Garuda No. 50 RewwinWaruSidoarjo.

\section{Sample}

[5] According are some of the population under study. In determining the sample, the researcher must ensure that the sample has represented the population. According to[9] that "Sample is a subgroup of the target population". It states that the sample is (accessible population). The subgroups of the target population are planned to be investigated by the researcher in order to take generalization of the target population. Meanwhile, according to [8] explains that the sample is part or representative of the population under study. If the population is too large and the researcher is not likely to study everything in the population, it can use samples taken from that population.

Sampling in this study was done as a whole (saturated sampling). Where saturated sampling is a sampling technique when all members of the population are used as samples. This is done because this research makes generalizations with very small errors. According[7] another term of the saturated sample is the census, where all members of the population are sampled.

\section{Data Collection Technique}

Data collection techniques are a means of measuring the dependent variable in an experiment can be observation, and scale or inventory depending on the needs of research[5]. While the data collection technique is a partial factor that is used in a study that will determine whether the poor research. This is in line with the opinion of [7]ie the quality of data collection with respect to the precise ways used to collect data. If do that from data collection techniques can be done by interview (interview), questionnaire, observation (observation) and the combination of all three.

Data collection techniques used in this study.

\section{a. Observation}

In this study the method used to obtain data, namely the method of observation. In the psychological sense according to arikunto [10] observation or so-called observation, including the activity of focusing attention to an object by using all the five senses. According[10] observations are divided into two, namely:

1) Non-systematic observations, i.e. those observed by observers with no use of observation instruments.

2) Systematic observations, i.e. those observed by observers using guidelines as an observation insulator.

3) In this study the researchers used a type of systematic observation to observe teachers and students in the process of teaching and learning activities by using media Modified dakon. The data collection in this study used observation sheet for students and for

4) teachers. The observation sheets are made of value based on the rating guidance with the values that have the rating rubies using the stars 1 , star 2 , star 3 , star 4 .

\section{Research Instruments}

The instrument of research is the measurement of ability to know the concept of number and fine motor ability. The instruments used are:

a. The result sheet understands the concept of numbers

Activity observation sheets are used to provide an assessment of the process of learning the concept of numbers in children. Measurement of children's learning ability in question is to know the ability to understand the concept of numbers in children. While the measurements in this study using a 1 to 4 star score, which will describe the level of ability of children. According to [7] Rating scale is a scale used to collect raw data in the form of numbers which are then interpreted in a qualitative sense.

\section{REFERENCES}

[1] Y. N. Sujiono, "Konsep dasar pendidikan anak usia dini," 2009.

[2] H. Susanto, "Towards practical implementations of membrane distillation," Chemical Engineering and Processing: Process Intensification, vol. 50, pp. 139-150, 2011.

[3] P. M. Pendidikan, "Kebudayaan (Permendikbud). 2013," Standar Proses Pendidikan Dasar dan Menengah. Jakarta: Permendikbud.

[4] I. Suparyogo, "Metode Penelitian Kuantitatif Kualitatif dan R\&D," Bandung: Alfabeta, 2001.

[5] M. Jannah, "Psikologi Eksperimen (Sebuah Pengantar," ed: Surabaya: Unesa University Press, 2016.

[6] C. R. Kothari, Research methodology: Methods and techniques: New Age International, 2004.

[7] A. Sugiyono and B. Anindhita, "Outlook Energi Indonesia 2014," Pusat Teknologi Pengembangan Sumberdaya Energi. Badan Pengkajian dan Penerapan Teknologi, 2014. 
[8] J. Sarwono, M. Arikunto, and M. S. Arikunto, "Metode Penelitian," Kuantitatif Kualitatif, 2006.

[9] J. W. Creswell, "Educational research," Planning, conducting, and evaluating quantitative and qualitative research, 2012.
[10] S. Arikunto, "Prosedur Penelitian: Suatu Pendekatan Praktik (Edisi Revisi 2010 Cetakan 14) Jakarta: PT Rineka Cipta," ed: ISBN, 2010. 